EGU2020-11307

https://doi.org/10.5194/egusphere-egu2020-11307

EGU General Assembly 2020

(c) Author(s) 2020. This work is distributed under

the Creative Commons Attribution 4.0 License.

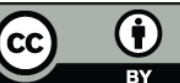

\title{
Birth of a large volcanic edifice offshore Mayotte (Comoros Island, Western Indian Ocean)
}

Nathalie Feuillet ${ }^{1}$, Stephan Jorry ${ }^{2}$, Wayne Crawford ${ }^{1}$, Christine Deplus ${ }^{1}$, Isabelle Thinon ${ }^{3}$, Eric Jacques $^{1}$, Jean-Marie saurel ${ }^{1}$, Anne Lemoine ${ }^{3}$, Fabien Paquet ${ }^{3}$, Claudio Satriano ${ }^{1}$, Chastity Aiken ${ }^{2}$, Angèle Laurent ${ }^{1}$, Cecile Cathalot ${ }^{2}$, Emmanuel Rinnert ${ }^{2}$, Arnaud Gaillot ${ }^{2}$, Carla Scalabrin'2, Manuel Moreira ${ }^{1}$, Aline Peltier ${ }^{1}$, François Beauducel ${ }^{1}$, Valerie Ballu' ${ }^{4}$, and the Tellus SISMAYOTTE and MAYOBS Team ${ }^{*}$

${ }^{1}$ Université de Paris, Institut de physique du globe de Paris, CNRS, F-75005 Paris, France

${ }^{2}$ IFREMER, Unité Géosciences Marines, Technopole La Pointe du Diable, 29280 Plouzané, France

${ }^{3}$ Bureau de Recherches Géologiques et Minières - BRGM, DGR/GBS, F-45060 Orléans, France

${ }^{4}$ LIttoral ENvironnement et Sociétés (LIENSs) UMR7266, Université de La Rochelle - CNRS, 2 rue Olympe de Gouges, 17000

La Rochelle

${ }^{*}$ A full list of authors appears at the end of the abstract

Volcanic eruptions are foundational events shaping the Earth's surface and providing a window into deep Earth processes. We document here an ongoing magmatic event offshore Mayotte island (Western Indian Ocean) unprecedented in terms of emitted volume of lava and duration of the seismic crisis.This event gave birth to a deep-sea volcanic edifice $820 \mathrm{~m}$ tall and $\sim 5 \mathrm{~km}^{3}$ in volume, located $50 \mathrm{~km}$ from Mayotte. A plume with distinct chemical signatures compared to openocean seawater emanated from the edifice, generating an exceptional 1900m-high vertical acoustic anomaly in the water column. Noble gas analyses in the vesicles from a popping rock dredged on the flank of the edifice, indicate rapid magma transfer from the asthenosphere. The edifice is located at the tip of a WNW-ESE-striking volcanic ridge composed of many other edifices, cones and lava flows constructed by past eruptions. Starting in May 2018 thousand of earthquakes were triggered by the magmatic event. The space-time distribution of the seismicity suggests that magma below the center of the ridge was transported to the new edifice over a few weeks in dikes that penetrated the brittle mantle a result of a lithosphere-scale extensional episode accommodating motion along a transfer zone between the East-African rifts and Madagascar. Since the eruption's onset, the seismicity is mostly concentrated closer to the island, in an exceptionally deep zone $(25-50 \mathrm{~km})$ overlain by a zone of enigmatic, very low frequency, tremors.

Tellus SISMAYOTTE and MAYOBS Team: Océane Foix, Philippe Kowalski, Jean-Pierre Donval, Vivien Guyader, Raphael Grandin, Romuald Daniel, Patrice Pelleau, Jeremy Gomez, Simon Besançon, Louis Geli, Pascal Bernard, Patrick Bachelery, Yves Fouquet, Didier Bertil, Arnaud Lemarchand, Jérome Van der Woerd. 